\title{
Modelling International Project Feasibility of Sustainable Construction Management: Case Study of Tele-Communication Towers
}

\author{
Samad M. E. SEPASGOZAR ${ }^{1,5}$, Gholam Reza SHIRAN ${ }^{2}$, Khalegh BARATI ${ }^{3}$ and Renard Y. J. \\ SIEW $^{4}$ \\ ${ }^{1-4}$ University of New South Wales, Australia \\ ${ }^{5}$ Corresponding author's e-mail: Sepas@unsw.edu.au
}

\begin{abstract}
This paper presents a new conceptual model for feasibility study of projects incorporating sustainability criteria. Large construction projects have an important influence on the attainment of sustainable development indices. Some of these projects particularly in developing countries have not sufficiently considered sustainability issues even with the participation of international companies in these projects during the feasibility phase as well as other phases such as design and operation. Previous studies have not addressed the relevance of the project feasibility phase in terms of sustainability performance. This paper is a result of the initial stages of an on-going study to develop a rigorous model of construction feasibility with sustainability considerations. Two case studies of similar construction projects were selected from two developing countries. The model for project feasibility study proposed in this paper includes economic, social, and environmental performance criteria in addition to traditional project criteria. The paper suggests there is an urgent need for shifting from the traditional approach of project feasibility study to a new approach embracing sustainability principles.
\end{abstract}

\section{KEYWORDS}

Feasibility; modelling; justification; criteria; sustainability; telecommunication towers

\section{INTRODUCTION}

Sustainability is one of the main concerns of politicians, policy makers across many industries including the construction sector (Siew et al., 2013; YJ Siew et al., 2013; Boz and El-adaway, 2014; Naderpajouh et al., 2014; Xia et al., 2014; Tommelein, 2015). Given the move towards sustainable construction, construction companies are expected to set up CSR policies as part of their procedures. CSR, defined as the responsibility of companies towards the environment and society (YJ Siew et al., 2013) are often overlooked in feasibility studies across many countries. Feasibility study is the first step, before undertaking project design. Traditionally, a project client or the consultant are involved in the feasibility study by determining financial issues, such as return of investment, demand and supply in the market and risk analysis on the market conditions. It has been argued that the project feasibility study is one of the most easily misunderstood aspects in developing a project (Shen et al., 2010). From a sustainability perspective, an effective feasibility study is much more than just a set of financial justifications, which sets the basis for all subsequent decisions. Rather a more holistic view encompassing environmental and social criteria should also be included. 
This paper presents a new conceptual model for feasibility study of infrastructure projects incorporating sustainability criteria. A feasibility study referred to as an evaluation of a proposal designed to determine the difficulty in carrying out a designated task is an important component in the project's life. As part of a feasibility study, there needs to be a formal process of providing justification. This paper intends to describe this concept in the project's life cycle in accordance to the World Bank.

\section{MODELLING}

\section{Industry Process for Justifying Projects}

In this section, an initial model for justification is presented. The model is based on the World Bank procedure for project justification to gain approval to commence planning for a large scale international engineering project. Figure 1 shows a project justification model that is developed in this study according to four phases. These phases are discussed using World Bank's types of feasibility.

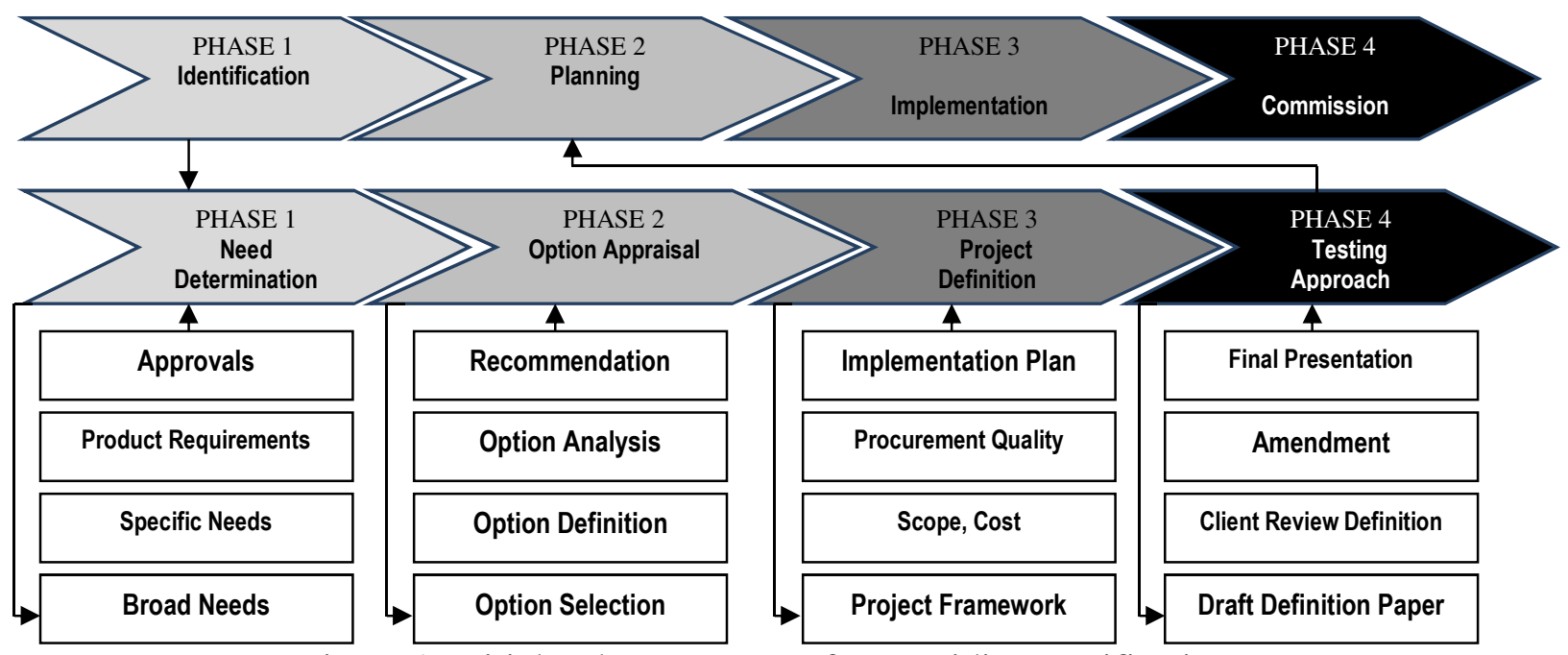

Figure 1. Initial Industry Process for Providing Justifications.

The types of feasibility include: technology and system feasibility; economic feasibility; legal feasibility; operational feasibility; market feasibility and procurement feasibility. These different types of feasibility can be used as a scope for project justification. Each will be discussed in turn.

\section{Technology and System}

Technology helps to improve productivity as well as efficiency and is therefore a crucial part of the project. Since technology has the potential to enhance efficiency, it is recognised to be an important business strategy (Devapriya and Ganesan, 2002; Rankin and Luther, 2006; Sepasgozar and Bernold, 2012; Sepasgozar and Bernold, 2012 ; Sepasgozar and Davis, 2014; Barati and Sepasgozar, 2015; Sepasgozar and Davis, 2015; Sepasgozar et al., 2015). Many governments continue to encourage companies to implement new technologies (e.g. MacGauran and Macfarlane, 2004; BCA, 2011; GCS, 2011; Brewer et al., 2012; Sepasgozar et al., 2014a; Sepasgozar et al., 2014b) to increase their level of competitiveness. 


\section{Economic}

Cost- benefit analysis and return on investment are important considerations. What are the benefits and savings that are expected from a project? Where will the funds come from? How will they be earned and spent? Have the cost/benefit analysis been conducted? How long time does it take to achieve a return on investments?

\section{Legal}

Another important issue is pertaining to legislations. Does the project conflict with any legislative requirements? This is an important consideration as it could possibly lead to exorbitant fines and loss of image/reputation if not properly adhered to. Construction companies would need to pay attention to good corporate governance but also other aspects including environmental and social legislations which may include environmental quality act or occupational safety and health acts among others.

\section{Operational}

Who will start and operate the project? What are their qualifications? One important aspect that has been neglected is the competency of the project team. Typically, competency is measured in terms of productivity and efficiency with little attention on sustainability attributes. Siew (2014) highlights eight sustainability competencies relating to construction projects which should be considered by project owners including safety auditing; managing environmental aspects, impacts and occupational health and safety (OHS) hazards; project risk management; safety recognition and award; safety/environmental reporting; monitoring contractors/subcontractors; communication; OHS regulations and management system.

\section{Market}

Who are the consumers or customers of the products or services? The four P's of marketing are described as product features, pricing, place or distribution, and promotion and advertising. The usual contents of a project feasibility study are as follows: background of the project, the objective of the project which should be specific, measurable, realistic and time-bounded, financial operations, projected cash flow, projected income statement, and projected statement of financial condition.

\section{Procurement}

Although the projects initiation consist of four phases as shown in Figure 1, according to the World Bank's procurement manual there are six stages that describe how the procurement process should take place under the project cycle. In this paper these phases are described. The objective of procurement activities within the United Nations (UN) system is the timely acquisition of goods, services and works while addressing the following principles:

1. The objective of the companies concerned

2. Fairness, integrity and transparency, through competition

3. Economy and effectiveness

4. Best value for money

\section{Organisational Procurement Strategy}

In all United Nations related companies, procurement has an impact on the overall company outcomes and results. Therefore, it is good practice to undertake strategic planning of 
procurement at the company level in order to link procurement activities and priorities to the overall priorities of the organization. An organizational procurement strategy is developed through a process of reviewing and analysing the companies:

1. Mandate, strategic direction and objectives

2. Procurement portfolio

3. Procurement function and capacity

\section{Identifying strategic procurement objectives}

Once the analytical phase is completed the next stage in developing the strategy is to identify strategic procurement objectives. These could be divided into:

1. Procurement objective for each category of work

2. Objectives for making significant purchases

3. Objectives for the management of the procurement function

\section{Procurement Process}

The ultimate goal of procurement planning is a coordinated and integrated system to fulfil a need for goods, services or works in a timely manner and at a reasonable cost. Most potential savings in the procurement process are achieved by improvements in planning. A good procurement planning is essential to optimize the contribution of the procurement function towards achieving overall goals of the organization. It clarifies what is needed and when it is needed to both user and buyer. Figure 2 shows each of these stages for an individual procurement planning process. A strategic approach to procurement assists an approved organization to consider these goals in a structured and justifiable way when choosing the best procurement procedure. A typical procurement planning process involves operational procurement planning; requirement definition; sourcing for vendors; selection of an appropriate procurement strategy; preparation and issuance of solicitation documents; receipt and opening of offers; evaluation of vendors; contract review and award; contract finalization and issuance and contract management. It would be best to measure the results to see if the objectives have been achieved. The ultimate objective of procurement is to add value to the organization by fulfilling its goals and objectives.

The World Bank`s procurement manual, describes six stages of gaining approval for a project and highlights the roles between a bank and the borrower as shown in Table 1. In the identification stage, the bank needs to determine whether a project has high priority and is suitable for the Bank. The role of the borrower at this stage is to initiate the project concept document containing details of the project and submits it to the Bank. If it is, there will be agreements between the bank and the borrower on relevant contract packages. The appraisal stage provides a comprehensive review of all aspects of procurement. The following procurement-related activities are carried out during appraisal:

1. The Borrower refines the preliminary procurement plan according to the conditions agreed in the preparation stage of the project.

2. A detailed Procurement Implementation Plan, for at least the first year after project approval and general plan for the entire project, is prepared by the Borrower.

3. The Bank decides whether the Borrower needs technical assistance

4. Where the Borrower intends to engage in advance contracting, the Bank determines whether there is a need to retroactively finance the procurement.

5. The Borrower begins the preparation of bidding documents for first year contracts. 
6. At this stage the Borrower is expected to initiate the setting up of systems for procurement record keeping and monitoring procurement performance that continue throughout the life of the project.

7. The Project Appraisal Document (PAD) provides summarizes the task team's assessments of various aspects of the project, and flags issues or areas that may be of special concern to the Bank.

Negotiations are the stage where the Bank and the Borrower endeavour to agree on the measures necessary to assure the success of the project. During negotiations, the Bank and Borrower discuss and finalize all procurement provisions in the Loan Agreement, including:

1. The action plan for the procurement organization and the type of technical assistance to be procured if any is required.

2. The co-financing of project components. The Bank does not usually finance all the aspects of the project.

3. Whether the borrower will use Bank Standard Bidding Documents for procurement

4. The monitoring arrangements and the papering requirements expected of the borrower.

Once the above issues have been agreed upon, they are converted into legal obligations on the Borrower's part and are set out in the Loan Agreement by the Legal Department. Implementation is the responsibility of the Borrower, with whatever assistance from Bank staff as has been agreed upon with the Bank. The objective of Bank supervision during the implementation stage of procurement and also during the entire process of procurement is not only to make sure that the borrower's procurement work is done properly and according to Bank policy, it is also to gather and accumulate experience to feed back into the design and preparation of future projects. Moreover, it also helps the Bank identify issues that need to be improved and may lead to recommendations for changes in Bank policies and procedures. Once the project is completed, the entire project is then reviewed and evaluated and actual results of the procurement are compared with the projected results in the original procurement plan.

\section{Justification}

According to the NSW Government Guidelines for Economic Appraisal, suitable justification must be provided in determining project feasibility. The following discussion outlines the steps which must be followed when preparing a standard economic evaluation.

Every proposal to spend money must have an underlying objective. The importance of specifying objectives when considering investment proposals cannot be over-stated. The worth of an investment can only be evaluated in terms of its objective(s).

There are five separate types of objectives for projects which may be relevant include: reduction in costs, increased savings, revenues and benefits to consumers not reflected in revenue flows, and benefits to the broader community. All economic evaluations should be based on incremental costs and benefits associated with a particular program. All relevant cost items which can be identified, quantified or estimated must be included. The stream of costs should cover the full project period which will be based on the economic life of the building or equipment. Assumptions underlying all estimates should be made explicit in the evaluation. Documentation of the economic evaluation should also include other relevant information which can affect the recommendation/decision. 
Table1. The stages of gaining approval

\begin{tabular}{|c|c|c|}
\hline $\mathbf{X}$ & Bank & Borrower \\
\hline Identification & $\begin{array}{l}\text { - Does the project have high priority and appear suitable } \\
\text { for the Bank? } \\
\text { - Will the business be profitable? When? Have the } \\
\text { cost/benefit analysis been conducted? }\end{array}$ & $\begin{array}{l}\text { - Initiation the project concept document. } \\
\text { - Submitting project document }\end{array}$ \\
\hline Preparation & - Agreements should be reached on the contract packages & $\begin{array}{l}\text { - Project Design and Start up } \\
\text { - Design procurement plan } \\
\text { - Phasing of the procurement } \\
\text { - The cost estimates } \\
\text { - Milestones to be used in monitoring } \\
\text { - The long term objectives of the program } \\
\text { - Procurement timetable }\end{array}$ \\
\hline Appraisal & $\begin{array}{l}\text { - Comprehensive review of all aspects of procurement } \\
\text { - Whether the Borrower needs technical assistance } \\
\text { - Where the Borrower intends to engage in advance } \\
\text { contracting }\end{array}$ & $\begin{array}{l}\text { - A detailed Procurement Implementation Plan } \\
\text { - Preparation of bidding documents for first year } \\
\text { contracts } \\
\text { - Initiate the systems for procurement monitoring } \\
\text { procurement performance }\end{array}$ \\
\hline $\begin{array}{l}\text { Negotiations and } \\
\text { Board } \\
\text { Presentation }\end{array}$ & $\begin{array}{l}\text { - Finalize all procurement provisions in the Loan } \\
\text { Agreement } \\
\text { - Finalize the co- financing of project components } \\
\text { - The methods of procurement to be used for the various } \\
\text { items } \\
\text { - The monitoring arrangements and the papering } \\
\text { requirements } \\
\text { - Finalize Standard Bidding Documents for procurement }\end{array}$ & $\begin{array}{l}\text { - Finalize all procurement provisions in the Loan } \\
\text { Agreement } \\
\text { - Finalize the co- financing of project components } \\
\text { - The methods of procurement to be used for the } \\
\text { various items } \\
\text { - The monitoring arrangements and the papering } \\
\text { requirements } \\
\text { - Finalize Standard Bidding Documents for }\end{array}$ \\
\hline $\begin{array}{l}\text { Implementation } \\
\text { and Supervision }\end{array}$ & $\begin{array}{l}\text { - Have a supervisory role to ensure that the } \\
\text { implementation process follows the procedures agreed } \\
\text { upon in the Loan Agreement }\end{array}$ & - Implementation is the responsibility of the Borrower \\
\hline Evaluation & - The entire project is reviewed and evaluated & \\
\hline
\end{tabular}

The costs and benefits which can be quantified are only part of an economic evaluation. Other aspects, such as environmental considerations, industrial relations, social or regional impact, safety, public relations, resource availability, and similar, will also have to be taken into account in choosing between competing options. Once all costs and benefits over the life of the project have been identified and quantified, they are expressed in present value. In doing these:

1. Costs and benefits should be valued in real terms: that is they should be expressed in constant dollars and increases in prices due to the general rate of inflation should not be included in the values placed on future benefits and costs.

2. The stream of costs and benefits (expressed in real terms) should be discounted by a real discount rate of 7 per cent, with sensitivity testing using discount rates of 4 per cent and 10 per cent.

3. Using the discounted stream of costs and benefits, the following decision measures should be calculated: Net present value (NPV); Net present value per $\$$ of capital outlay (NPVI); Benefit-cost ratio (BCR); Internal rate of return (IRR).

\section{CASE STUDIES}

Two international projects were selected for the case study: Milad Tele-communication Tower (Iran), and KL Tower (Malaysia). These towers have a multi-purpose function and are 435 meters and 421 meters tall respectively. The tower structures comprise of a shaft, head structure, observation deck, sloped roof, tier levels, and a sky dome. Table 2 shows the main criteria that 
have been considered in these case studies. Particular attention was paid to the different phases of feasibility study and other criteria that were incorporated in these projects.

Table 2. The comparison of the selective key criteria in the cases studies

\begin{tabular}{|l|l|c|c|}
\hline \multicolumn{1}{|c|}{ CD } & \multicolumn{1}{|c|}{ Criteria } & $\checkmark$ & KL Tower \\
\hline F10 & Quality Control Procedure & $\checkmark$ & $\checkmark$ \\
\hline F11 & Maintenance Manual & - & - \\
\hline F21 & Noise criteria & $\checkmark$ & $\checkmark$ \\
\hline F15 & Defects Liability Period & $\checkmark$ & $\checkmark$ \\
\hline F16 & Guarantees for sub-contractors & $\checkmark$ & $\checkmark$ \\
\hline F17 & Insurance & $\checkmark$ & $\checkmark$ \\
\hline F18 & Scope of Works & - & $\checkmark$ \\
\hline F25 & Cultural conservation & $\checkmark$ & $\checkmark$ \\
\hline F05 & Investment plan & $\checkmark$ & $\checkmark$ \\
\hline F06 & Cost & $\checkmark$ & $\checkmark$ \\
\hline F12 & Commissioning & $\checkmark$ & $\checkmark$ \\
\hline F01 & Need Identification & $\checkmark$ & $\checkmark$ \\
\hline F08 & Option Appraisal & $\checkmark$ & $\checkmark$ \\
\hline F02 & Project Definition & $\checkmark$ & $\checkmark$ \\
\hline F09 & Testing Approach & & $\checkmark$ \\
\hline
\end{tabular}

\section{DEVELOPING THE CONCEPTUAL MODEL}

Figure 4 shows the construction project feasibility model (CPFM) that consists of four phases namely need identification, option appraisal, project definition and testing approach adopted from the case studies. The model also incorporates sustainability criteria classified into: environmental, social, and finance.

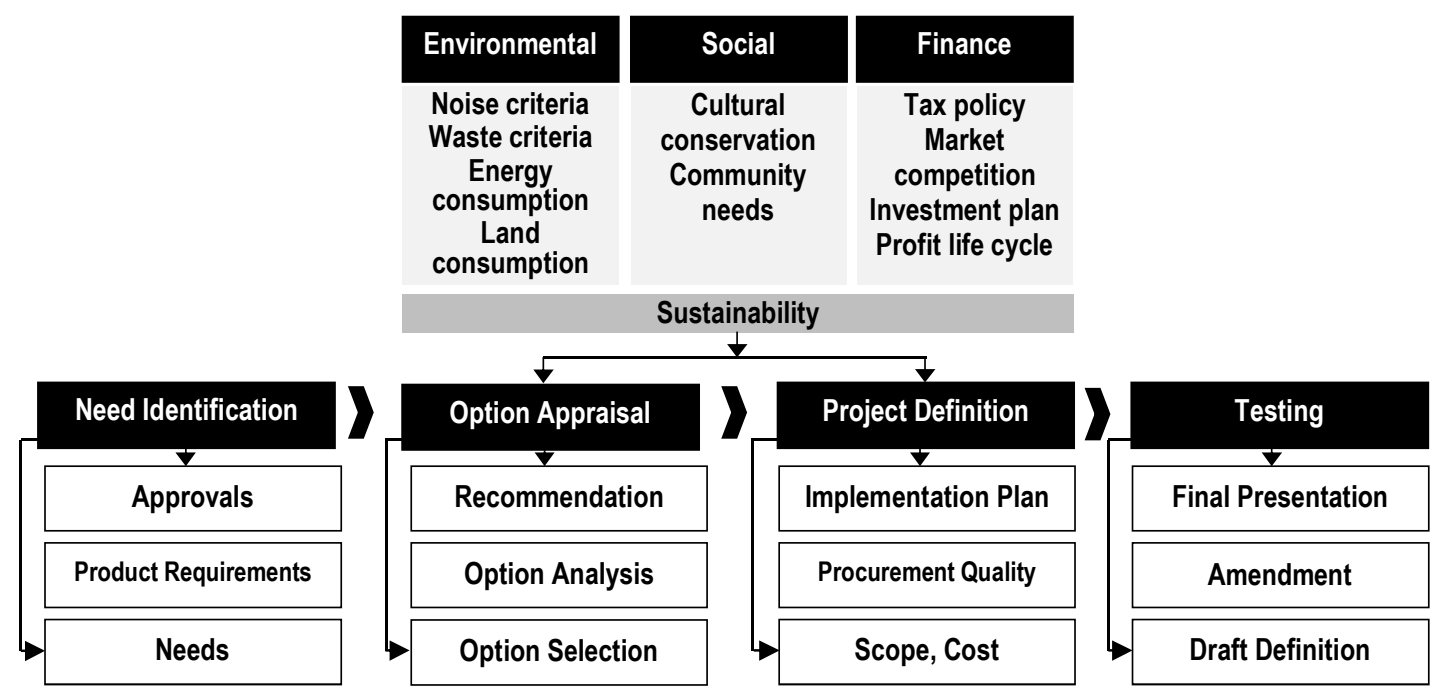

Figure 4. Construction project feasibility model (CPFM). 


\section{CONCLUSION}

This paper presents a feasibility model incorporating sustainability criteria with reference to two international tele-communication towers. This paper describes the feasibility concepts in terms of a project's life cycle. This paper also focuses on how to provide a suitable justification for the project in line with the NSW Government Guidelines for Economic Appraisal. Based on the findings from the case studies, both social and environmental criteria are given limited or no consideration. For example, cultural and heritage conservation and environmental friendly design are ignored. The study argues that there is an urgent need for shifting from traditional approach of feasibility study in construction projects to a new approach which embraces sustainability principles. The structure of CPFM for a project feasibility study includes four phases such as: need identification, option appraisal, project definition and testing with sustainability criteria. Future research will investigate the effectiveness of the CPFM model for conducting new project feasibility. It will be presented to construction practitioners and other stakeholders for further feedback and refinement.

\section{REFERENCES}

Barati, K. and Sepasgozar, S. M. E. (2015) "Factors Affecting on Productivity of Oil and Gas Construction Projects: An Ahp Analysis", American Journal of Civil Engineering and Architecture, 3(1), 21-27.

BCA (2011) 'International Experts Impressed with Bca's Plans to Transform Singapore's Building and Construction Sector', Press Releases, available: [accessed March 2015].

Boz, M. A. and El-adaway, I. H. (2014) "Creating a Holistic Systems Framework for Sustainability Assessment of Civil Infrastructure Projects", Journal of Construction Engineering and Management, 141(2).

Brewer, G., Gajendran, T. and Goff, R. L. (2012) Building Information Modelling (Bim): Australian Perspectives and Adoption Trends, Tasmanian Building and Construction Industry Training Board: Tasmanian Building and Construction Industry Training Board.

CPDC (Chair of the Professional Development Council) (2008) AIPM Professional Competency Standards for Project Management - Part A, AIPM Professional Competency Standards for Project Management, Australian Institute of Project Management, November 2008 Version 1.00

Crawford, L. (2007) Professional Associations and Global Initiatives, in The Wiley Guide to Managing Projects (eds P. W. G. Morris and J. K. Pinto), John Wiley \& Sons, Inc., Hoboken, NJ, USA. doi: 10.1002/9780470172391.ch56.

Devapriya, K. A. K. and Ganesan, S. (2002) "Technology Transfer Subcontracting in Developing Countries Through", Building Research \& Information, 30(3), 171-182.

Dinsmore 2011. Amacom Books, 3rd Edition.

GCS (2011) Government Construction Strategy, London: UK Cabinet Office.

MacGauran, P. and Macfarlane, I. (2004) Construction 2020 a Vision for Australias Property and Construction Industry, Brisbane, Australia: CRC for Construction Innovation.

Morris, Peter and Pint, J. K. 2007. Global body of project management knowledge \& Standards.

Naderpajouh, N., Mahdavi, A., Hastak, M. and Aldrich, D. P. (2014) "Modeling Social Opposition to Infrastructure Development", Journal of Construction Engineering and Management, 140(8).

NZ Transport Agency 2011. Procurement manual: for activities funded through the National Land Transport Programme, First edition, effective from July 2009. 
Paul C. Dinsmore, Jeannette Cabanis-Brewin Caupin, G., H. Knopfel, P. Morris, E. Motzel, E. and $\mathrm{O}$. The AMA Handbook of Project Management

Rankin, J. H. and Luther, R. (2006) "The Innovation Process: Adoption of Information and Communication Technology for the Construction Industry", Canadian Journal of Civil Engineering, 33(12), 1538-1546.

Sepasgozar, S. M. and Bernold, L. E. (2012) Factors Influencing the Decision of Technology Adoption in Construction, translated by ASCE, 654-661.

Sepasgozar, S. M. and Davis, S. R. (2015) A Decision Framework for Advanced Construction Technology Adoption, translated by.

Sepasgozar, S. M. E. and Bernold, L. E. (2012 ) A Technology Pre-Adoption Model for Construction, translated by Sydney.

Sepasgozar, S. M. E. and Davis, S. (2014) "Diffusion Pattern Recognition of Technology Vendors in Construction" in Construction Research Congress 2014, 2106-2115.

Sepasgozar, S. M. E., Lim, S., Shirowzhan, S. and Kim, Y. M. (2014b) "Implementation of asBuilt Information Modelling Using Mobile and Terrestrial Lidar Systems", in The 31st International Symposium on Automation and Robotics in Construction and Mining (ISARC 2014), Sydney, IAARC,

Sepasgozar, S. M. E., Razkenari, M. A. and Barati, K. (2015) "The Importance of New Technology for Delay Mitigation in Construction Projects", American Journal of Civil Engineering and Architecture, 3(1), 15-20.

Sepasgozar, S. M., Lim, S. and Shirowzhan, S. (2014a) Implementation of Rapid as-Built Building Information Modeling Using Mobile Lidar, translated by ASCE, 209-218.

Shen, L.-y., Tam, V. W. Y., Tam, L. and Ji, Y.-b. (2010) "Project Feasibility Study: The Key to Successful Implementation of Sustainable and Socially Responsible Construction Management Practice", Journal of Cleaner Production, 18(3), 254-259.

Siew, R. Y. J., Balatbat, M. C. A. and Carmichael, D. G. (2013) "The Relationship between Sustainability Practices and Financial Performance of Construction Companies", Smart and Sustainable Built Environment, 2(1), 6-27.

The Wiley guide to project organization \& project management competencies, Peter Morris, Jeffrey K. Pinto 2007

Tommelein, I. D. (2015) "Journey toward Lean Construction: Pursuing a Paradigm Shift in the Aec Industry", Journal of Construction Engineering and Management.

United Nations (2006) UN Procurement Practitioner's Handbook. Common Procurement Certification Scheme for the United Nations (UN)

Xia, B., Skitmore, M., Wu, P. and Chen, Q. (2014) "How Public Owners Communicate the Sustainability Requirements of Green Design-Build Projects", Journal of Construction Engineering and Management, 140(8).

YJ Siew, R., CA Balatbat, M. and G. Carmichael, D. (2013) "A Review of Building/Infrastructure Sustainability Reporting Tools (Srts)", Smart and Sustainable Built Environment, 2(2), 106-139. 